\title{
DEVELOPING A SUSTAINED AND COORDINATED U.S. COASTAL RESEARCH PROGRAM
}

\author{
Nicole Elko, American Shore and Beach Preservation Association, nicole.elko@asbpa.org \\ Jeff Lillycrop, U.S. Army Corps of Engineers Engineering Research and Development Center, \\ jeff.lillycrop@usace.army.mil \\ John Haines, U.S. Geological Survey Coastal Marine Geology Program, ihaines@usgs.gov \\ Hilary Stockdon, U.S. Geological Survey Coastal Marine Geology Program, hstockdon@usgs.gov
}

To address societal needs along the coast, a community of researchers from Federal agencies, academia, industry, \& NGOs are developing a National science plan. The goal is to identify and address research priorities through better coordinated Federal activities to enhance funding sources, strengthen academic programs, and build a skilled workforce.

This abstract describes a grassroots effort, initiated by researchers, that has led to meaningful engagement from the coastal community and swift action to build a National plan. The effort began in Mar 2014 when academic \& Federal researchers, convened the Future of Nearshore Processes Workshop to develop a research vision to address societally-relevant coastal science challenges. They organized science needs in three broad research themes, 1) long-term coastal evolution 2) extreme events and 3) human and ecosystem health, identified a need to strengthen science infrastructure (e.g. observations and modeling) and recommended creation of a U.S. Coastal Research Program and Nearshore Advisory Council (NAC) to support the vision (Nearshore Processes Community 2015).

In Feb 2016, a Leadership Council composed of Federal agencies, the NAC, and the American Shore and Beach Preservation Association agreed to collaborate to implement these recommendations. Subsequently, Federal and academic researchers compared ongoing coastal research projects to find potential collaboration opportunities and identify topics of societal interest for which science advancements are required. Results were summarized in the first iteration of a National Plan (Figure 1). Discussion of this plan at the $1^{\text {st }}$ National Nearshore Collaboration Workshop resulted in 14 opportunities for multi-agency collaborations to enhance the impact and value of investments in coastal research, including funding academic collaborators. The purpose of this abstract is to inform coastal researchers of the ongoing effort and solicit input for the Leadership Council as it determines the next steps in establishing a formal National Program.

\section{REFERENCE}

Nearshore Processes Community (2015): The Future of Nearshore Processes Research. Elko N, Feddersen F, Foster D, Hapke C, McNinch J, Mulligan R, Ozkan-Haller $\mathrm{T}$, Plant N, and Raubenheimer B (Eds), Shore \& Beach, vol. 83(1), pp. 13-38.

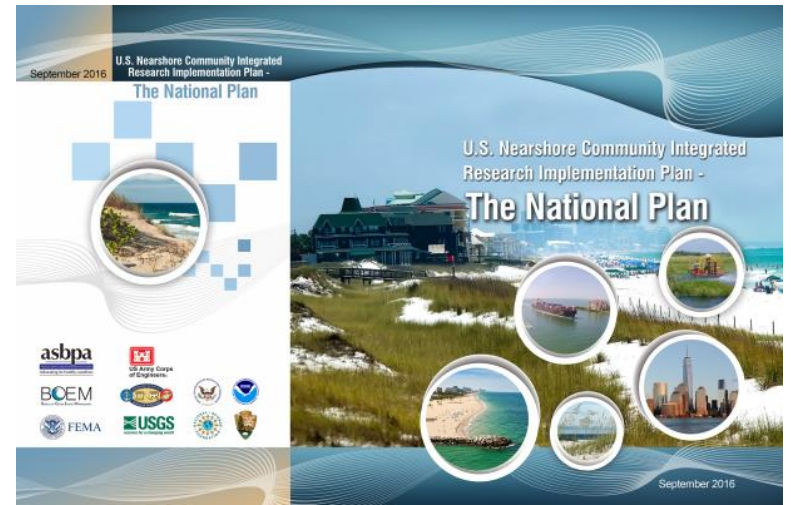

Figure 1 - Cover of the National Plan, a 116 pg. report that inventories over 260 federal and non-federal U.S. coastal research projects, describes potential collaborations and gaps in ongoing research, and provides 11 implementation recommendations. 